\title{
The Effect of Institutional Quality on the Balance of Payments in African Countries. A Comparative Study
}

\author{
Ashraf Helmy ${ }^{1}$ \\ ${ }^{1}$ Faculty of Economics and International Trade, Egyptian Chinese University, Cairo, Egypt \\ Correspondence: Ashraf Helmy, Associate Professor of Economics, Faculty of Economics and International \\ Trade, Egyptian Chinese University, Cairo, Egypt. ORCDI: 0000-0001-7543-8785. E-mail: ahelmy@ecu.edu.eg
}

Received: May 12, 2021

Accepted: June 4, 2021

Online Published: June 12, 2021

doi:10.5539/ijef.v13n7p55

URL: https://doi.org/10.5539/ijef.v13n7p55

\begin{abstract}
This study tries to examine the effect of the quality of the institutional framework on the accounts of the balance of payments in a sample of African countries (28 countries) and a sample of countries occupying advanced positions in international economics (15 countries) to determine different indicators of the institutional framework that affect the balances of the current and financial accounts of the balance of payments in the two sample countries through the period 2002-2019. The study applied the panel autoregressive distributed lag (ARDL) model, Akaike info criterion (AIC), to determine the short- and long-run relationships.

The empirical findings illustrate that the institutional indicators that support the current accounts of the balance of payments, in the long run, are not the same that support the financial accounts of the balance of payments of African countries. In addition, the effect of institutional indicators on international transactions is related to the level of economic development, where the effect of institutional indicators on countries with relatively low levels of economic development is more powerful than their effects on countries with advanced levels of development. Thus, the low quality of the institutional framework is considered an important impediment to the development of international transactions in African countries.
\end{abstract}

Keywords: institutional, government effectiveness, African, current account, financial account, balance of payments

JEL: E02, F32, O43, P33, O57.

\section{Introduction}

\subsection{Overview}

The processes of economic growth and development do not just depend on the number and quality of factors of production available in the economy but also on the quality of the institutional framework surrounding these processes. The quality of the institutional framework allows one country to allocate and use its available resources in more efficient ways and introduce high numbers and quality of outputs that exceed the ones introduced by other countries with the same or even higher resources (Hall \& Jones, 1999; Shah \& Huther, 1998). Moreover, the quality of the institutional framework supports the process of innovation and allows for generating and introducing new ideas in the economy (Duho et al., 2020). The differences in the patterns and rates of economic growth among countries with the same resources have made doubts regarding the belief that economic growth stems just from capital accumulation and the contribution of labor and other factors of production (North \& Thomas, 1973). Accordingly, it can be said that government effectiveness and quality of institutional framework are prerequisites to the process of economic growth. According to the Solow growth model, the level of economic growth in developing and developed economies will ultimately converge and reach a steady-state level of output, where developing economies are growing faster than the developed ones (Solow, 1956). In other words, the rate of growth of the developed and developing economies will converge through the steady-state path and ultimately reach the cutting-edge (McQuinn \& Whelan, 2007). The convergence between the growth in the developed and developing economies is a conditional one, and the most crucial condition is that the status of the institutional framework holds the same in all economies. Empirically, economies with the same endowments of resources are subject to economic growth divergence rather than growth convergence, thanks to the effectiveness of the institutional framework in these economies. In addition, an effective 
institutional framework can set a pattern of economic growth enables for maximizing the economic and social benefits of using the available resources (Ali \& Zhuang, 2007). One of the desired economic growth patterns is the one that promotes the position of the economy in international economics. For African countries, integration into the global economy is one of the four main goals designed by the New Partnership for Africa's Development program (African Union, 2001). A major reason that stands behind the deterioration in the international trade indicators of most of the Sub-Saharan Africa countries is the inefficient institutional framework in this region (Osabuohien, 2011), where the majority of African countries exports are income inelastic products, a character that stands behind the deterioration in the balance of trade (Tharnpanich \& Mccombie, 2013). Moreover, the quality of the institutional framework is an attractive stimulus to foreign direct investment (Sabir et al., 2019). In light of the previous illustration, it can be said that the quality of the institutional framework can affect the balances of the current and financial accounts of the balance of payments.

\subsection{Study Problem}

Several measures to promote the accounts of the balance of payments have been observed in many African countries, devaluation of local currencies, tax facilities, and granting subsidies are on the top of these measures; however, all these efforts did not bear fruit, where these countries maintained relatively low positions in international economics. The previous observations highlight other factors that may have an indirect effect on the balance of payments. On top of these factors is the institutional framework surrounding the business, where countries that occupy advanced positions in international economics achieved relatively higher scores regarding the institutional indicators.

\subsection{Study Objectives and Layout}

This study tries to examine the effect of the quality of the institutional framework on the accounts of the balance of payments in a sample of African countries and a sample of countries occupying advanced positions in international economics to determine different indicators of the institutional framework that affect the balances of the current and financial accounts of the balance of payments in the two samples, as depicted in Figure 1. Figure 1 illustrates the six pillars or indicators of the institutional framework, namely control of corruption, rule of law, political stability, voice and accountability, regulatory quality, and government effectiveness. These aspects are expected to influence the current and financial accounts of the balance of payments. The study will try to examine the effect of these institutional indicators on the current and financial accounts of the African countries and a sample of countries (reference countries) occupying good positions in the current and financial international transactions. Finally, the study will make a comparison between the two sample countries to determine the available channels to improve the positions of African countries in international transactions.

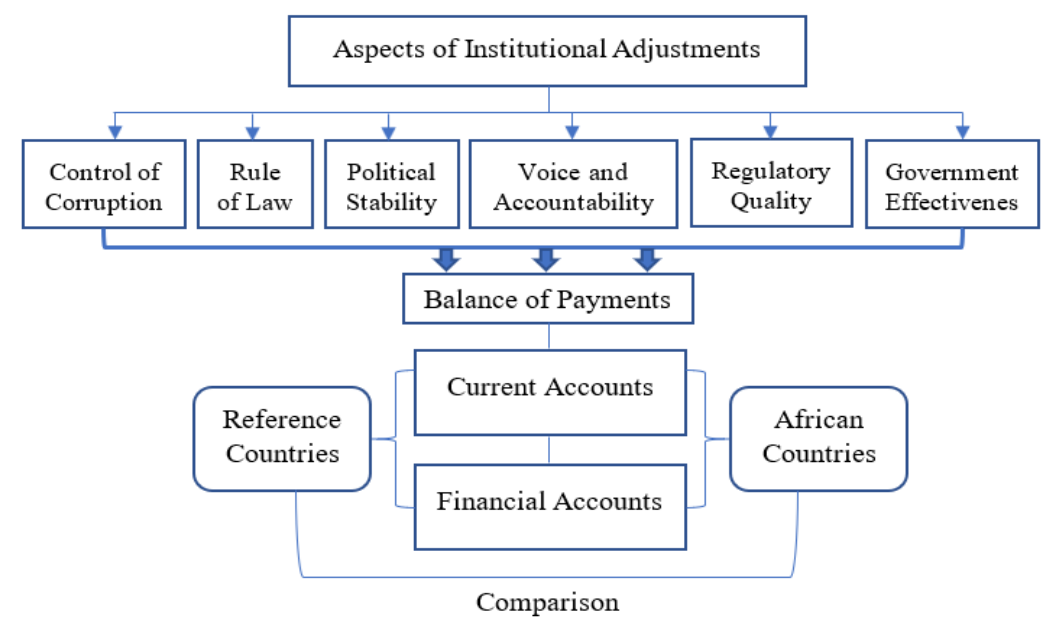

Figure 1. The study layout

\subsection{Study Hypotheses}

- The inefficiency of the institutional frameworks in African countries stands behind their lagged position in international economics.

- The institutional indicators that affect the current accounts of the balance of payments in African countries differ from the ones that affect the financial accounts. 


\subsection{Methodology}

This study applies the panel autoregressive distributed lag (ARDL) model, Akaike info criterion (AIC), to estimate the effect of different institutional aspects on the current and financial accounts of the balance of payments in the short and long run.

\subsection{The Scope of the Study}

This study examines the development of the institutional indicators and the balances of current and financial accounts of the balance of payments in two sample countries during the period 2002-2019. One sample includes 28 African countries, while the other one is the reference sample and includes 15 countries that managed to achieve simultaneous success in both accounts of the balance of payments.

\subsection{Sources of Data}

Data are collected from the World Development Indicators and Worldwide Governance Indicators database of the World Bank.

\subsection{Research Plan}

Section (1): Introduction.

Section (2): Literature Review.

Section (3): The Development of Institutional Indicators and Balance of Payments Accounts in the Sample Countries.

Section (4): Econometric Analysis and Empirical Findings.

Section (5): Concluding Remarks and Recommendations.

\section{Literature Review}

This section illustrates the empirical literature regarding the effect of the institutional frame work and government effectiveness on the performance of the economy.

The study of Fayissa and Nsiah (2013) applied fixed and random effects and Arellano-Bond models on data extracted from 28 Sub-Sahara African countries for the period 1990-2004 and concluded that differences in the quality of institutional aspects stand behind the divergence of per-capita income in the Sub-Sahara African countries. Moreover, inefficiency in setting appropriate institutional frameworks in African countries is considered the main impediment to the achievement of the New Partnership for Africa's Development goals. The study of Han et al. (2014) applied the Dynamic Generalized Method of Moments and panel model to determine the effect of the degree of institutional quality on the economic development in a sample of countries from different regions during the period 1998-2011. The study argued that the six institutional indicators have a powerful positive impact on the status of economic growth and per-capita income. Besides, the response of economic performance to the degree of institutional quality is relatively weak in Asian countries; however, the two institutional indicators, namely government effectiveness and regulatory quality, have a significant impact on the economic performance in Asia compared to other countries all over the world. The study of Emara and Chiu (2016) used the Principal Components Analysis method to prepare a composite governance index and applied regression analysis on cross-sectional data of 188 countries for the years 2009 and 2013 to determine the effect of the quality of governance on the economic growth process. The study found that economic growth strongly responds to the improvement in the governance index and that the modest and unstable levels of economic growth achieved by most middle eastern and north African countries are attributed to weak governance reasons. The study of Alam (2017) applied the Generalized Method of Moments on panel data of 81 economies for 13 years to estimate the effect of government effectiveness on the process of economic growth and concluded that the effect of government effectiveness on economic growth varies according to the level of income. The study concluded that control of corruption has a positive and significant effect on economic growth while political stability and the absence of violence and terrorism have weak positive effects on economic growth. The study of Butkus and Šeputienè (2018) applied the Generalized Method of Moments and System-Generalized Method of Moments on a sample of 152 economies for the period 1996-2016 to estimate the factors that determine the turning point of the positive effect of debt on economic growth. The study argued that despite government effectiveness is an important determinant of the debt turning point; however, the trade balance is a more critical determinant of this point. The study of Nikzadian et al. (2019) examined the effect of government effectiveness on the efficiency of allocating and utilizing resources and applied panel data analysis on oilexporting countries for the period 2002-2015 and argued that government effectiveness is most necessary to make the best utilization of oil revenues in the oil-exporting countries. The study of Sabir et al. (2019) applied 
the system Generalized Method of Moments on data collected from a sample of countries with different levels of economic development for the period 1996-2016 to examine the effect of institutional quality on foreign direct investment. The study found that the quality of institutional framework positively affects the flows of foreign direct investment in all countries in the sample; however, the response of FDI to the quality of institutional framework is relatively higher in developed countries compared to the developing ones. The study of Hayat et al. (2019) applied the system Generalized Method of Moments on panel data collected from a sample of 104 countries for the period 1996-2015 to examine the indirect effect of the quality of institutional framework on economic growth through the flows of foreign direct investment. The study argued that the spillovers of foreign direct investment on economic growth in countries with high-quality institutional frameworks are relatively high compared to countries with low-quality institutional frameworks. The study of Montes et al. (2019) applied panel data analysis on a sample of 82 developed and developing economies for the period 2006-2014 to examine the effect of fiscal transparency on government effectiveness and debt. The study argued that an increase in fiscal transparency would improve government effectiveness and reduce government debt. The study of Şaşmaz and Sağdiç (2020) applied panel data models on 11 transition economies in the European Union for the period 20022018 to examine the effect of government effectiveness and the rule of law on the economic performance of these countries. The study argued that government effectiveness has a significant positive effect on economic growth, while the rule of law indicator has no significant effect on the process of economic growth. The study of Radulović (2020) examined the effect of institutional quality on economic growth in European Union countries and non-EU economies of Southeast Europe during the period 1996-2017 by applying the Autoregressive Distributed Lag model. The study argued that all the institutional indicators have positive long-run relationships with economic growth and this relationship is not valid in the short run. For the non-EU economies, all institutional indicators, but the rule of law, have positive long-run relationships with economic growth, while in the short-run, just regulatory quality and voice and accountability indicators have positive effects on economic growth. The study of Duho et al. (2020) applied the panel-corrected standard error regression on data collected from 100 countries in Asia and Africa for the period 2002-2018 to examine government effectiveness in Asian and African countries and determine the degree of convergence in governance between these countries. The study concluded that governance indicators are performing much better in Asian countries than in African countries except for voice and accountability and press freedom. In addition, there are five indicators with significant positive impacts on government effectiveness, namely regulatory quality, voice and accountability, economic wealth, minimizing corruption, and government size, while freedom of the press negatively affects government effectiveness.

\section{What is new with this study?}

This study examines the short- and long-run effect of institutional quality on the international transactions of African countries represented by the balances of the current and financial accounts of the balance of payments of a sample of 28 African countries. To develop a benchmark, the same examination will be applied on a sample of 15 countries that managed to achieve simultaneous success in both accounts of the balance of payments. Based on the outcomes of the two examinations, optimal procedures regarding institutional quality indicators to improve the positions of African countries in international economics will be determined.

\section{The Development of Institutional Indicators and Balance of Payments Accounts in the Sample Countries}

\subsection{The Reference Countries}

The reference sample includes countries that managed to maintain advanced positions in the balance of payments accounts and countries that managed to improve their positions in international economics through the study period. Figure 2 illustrates the development of the balances of current accounts through the periods 2002-2010 and 2011-2019. The performance of the current accounts of the reference countries fluctuated through the two sub-periods of the study; however, the average balances of all countries fluctuated within the positive area through the period 2011-2019. Countries like Germany, Italy, South Korea, Spain, Singapore, and the Netherlands managed to significantly improve the status of their current accounts through the period 2011-2019. Other countries, such as Denmark, Kuwait, Russian Federation, Saudi Arabia, Switzerland, and Thailand, either managed to maintain or modestly improve the status of their current accounts through the second sub-period. In addition, countries like Denmark, Germany, Singapore, Spain, Sweden, and Switzerland managed to improve the stability of the performance of their current accounts where the standard deviations of these countries recorded $5.2,72.9,13.2,9.7$, and 21.3 billion US\$, respectively, during the period 2002-2010 and these records reduced to 3.7, 32.3, 4.9, 7.4, and 14 billion US\$, respectively, through the period 2011-2019. 

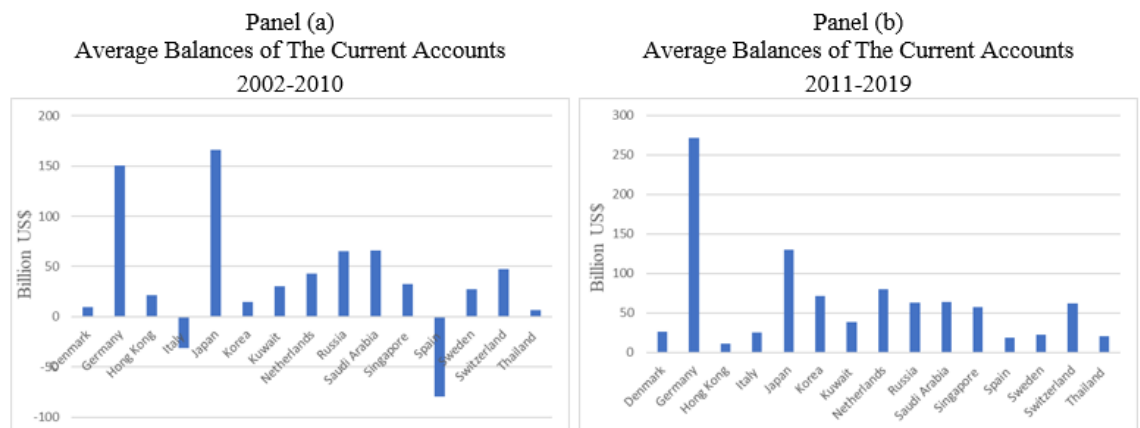

Figure 2. Development of the balances of current accounts of the reference countries

Source: World Bank, World Development Indicators Data Base.

Regarding the financial accounts, Figure 3 illustrates the development of financial accounts balances through the periods 2002-2010 and 2011-2019. Countries like Italy and Spain managed to turn their financial deficits, during the period 2002-2010, into financial surpluses, through the period 2011-2019. Germany, South Korea, Netherlands, and Singapore managed to significantly improve the status of their financial accounts through the period 2010-2019. Despite the financial balances of all reference countries have fluctuated within the positive area through the period 2011-2019; however, the status of some balances has deteriorated through the second sub-period, like the case of Hong Kong and Japan. What is worth noting is that the balances of financial accounts are much volatile, where the standard deviations of the financial balances of most countries in the sample have been significantly increased in the second sub-period of the study relative to the first one.

Panel (a)

Average Balances of The Financial Accounts 2002-2010

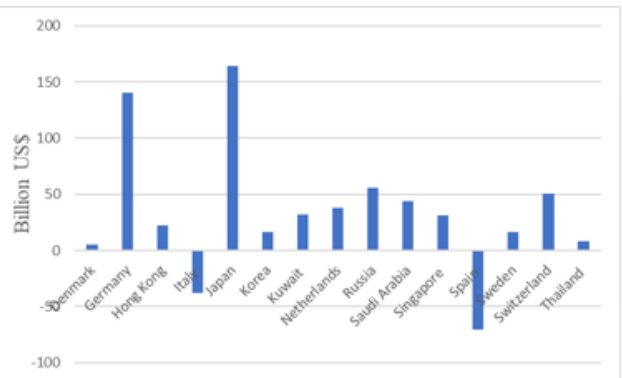

Panel (b)

Average Balances of The Financial Accounts 2011-2019

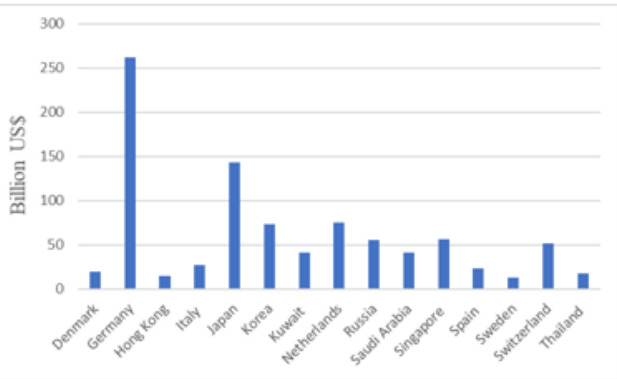

Figure 3. Development of the balances of financial accounts of the reference countries

Source: World Bank, World Development Indicators Data Base.

Through the study period, four reference countries witnessed deteriorations in the six indicators of the institutional quality, namely Denmark, Kuwait, Italy, and Thailand, as illustrated in Figure 4. The six institutional indicators, namely control of corruption, government effectiveness, political stability (No Violence), rule of law, voice and accountability, and regulatory quality, are represented by the numbers $1,2,3,4,5$, and 6 , respectively, in Figure 4 and the forthcoming figures.

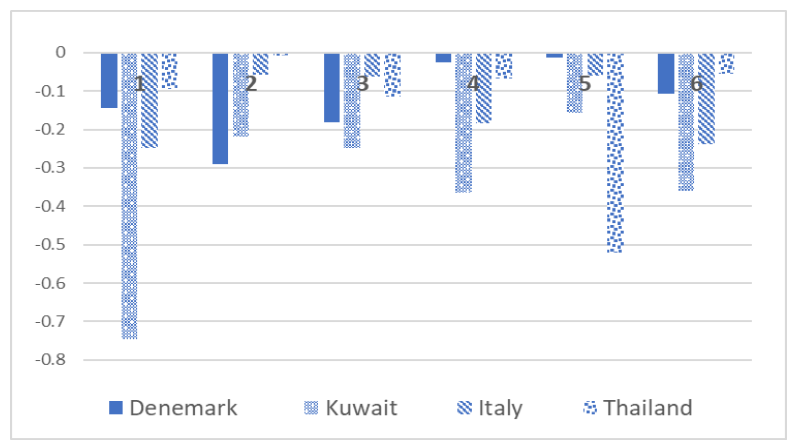

Figure 4. Reference countries that witnessed a decline in all institutional indicators during the study period Source: World Bank, Worldwide Governance Indicators database. 
Unlike the rest of the reference countries, Japan managed to achieve progression in the six institutional indicators, while the rest of the reference countries experienced deterioration in one or more of the six institutional indicators. Figure 5 shows that the majority of reference countries were suffering problems in two main institutional quality indicators, namely control of corruption and political stability indicators; on the other hand, most countries performed better concerning rule of law and government effectiveness indicators. Few countries were suffering problems in the other two institutional indicators voice and accountability and regulatory quality.

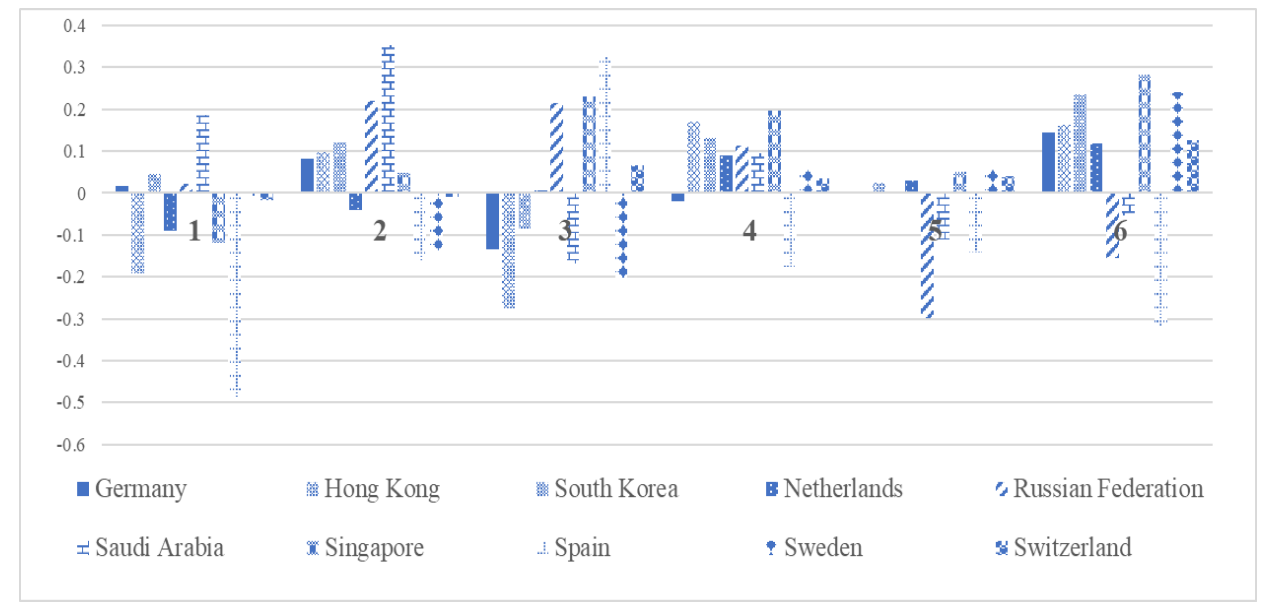

Figure 5. The development of the institutional indicators during the study period

Source: World Bank, Worldwide Governance Indicators database.

\subsection{The African Countries}

The African continent is represented in this study by 28 African countries chosen according to size, importance, and availability of data. Figure 6 indicates that all the African countries in the sample experienced deterioration in the balances of their current accounts through the study period. Moreover, the balances of 21 African countries in the sample turned into deficits through the period 2011-2019.

Panel (a)

Average Balances of The Current Accounts

2002-2010

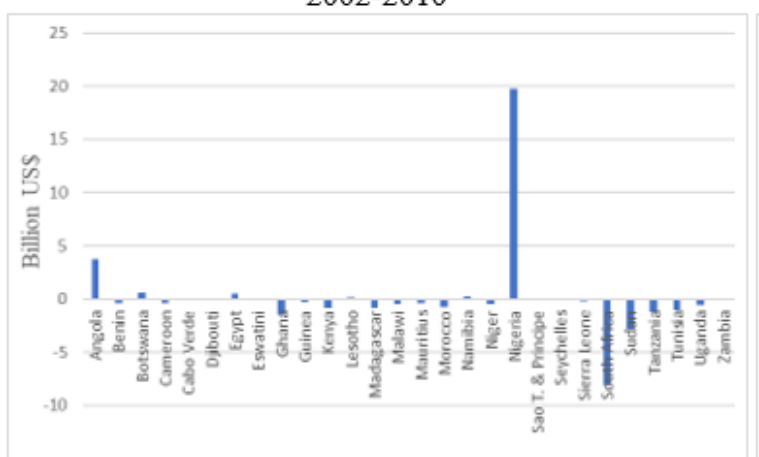

Panel (b)

Average Balances of The Current Accounts

2011-2019

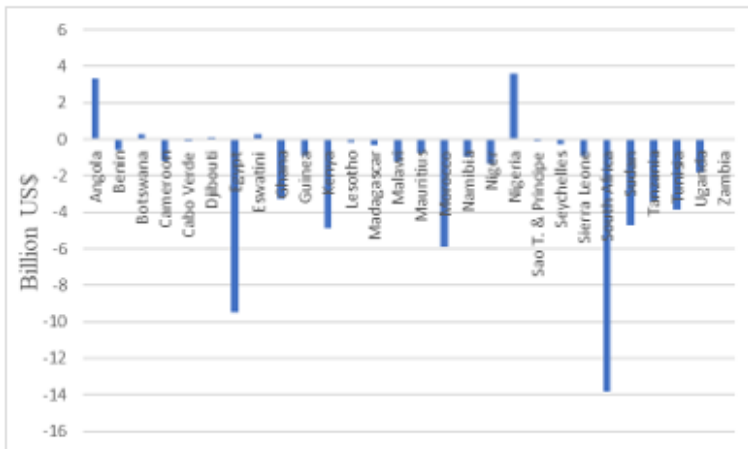

Figure 6. Development of the balances of current accounts of the sample of African countries

Source: World Bank, World Development Indicators Data Base.

The situation is much worse for the balances of the financial accounts, where all the African countries in the sample suffered deterioration in their financial accounts; besides, almost all the countries have experienced severe financial deficits. Figure 7 shows significant changes in the balances of financial accounts during the period 2011-2019 relative to the preceding period where several balances turned into a deficit. The volatility of the balances of both the current and financial accounts is very high, where the average balances of the current and financial accounts recorded -0.86 and -0.99 billion US $\$$ with standard deviations of 5 and 4.5 billion US\$, respectively. 
Panel (a)

Average Balances of The Financial Accounts 2002-2010

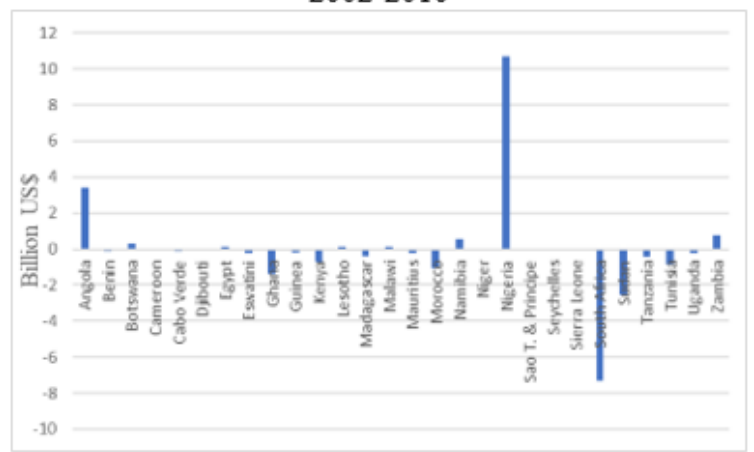

Panel (b) Average Balances of The Financial Accounts 2011-2019

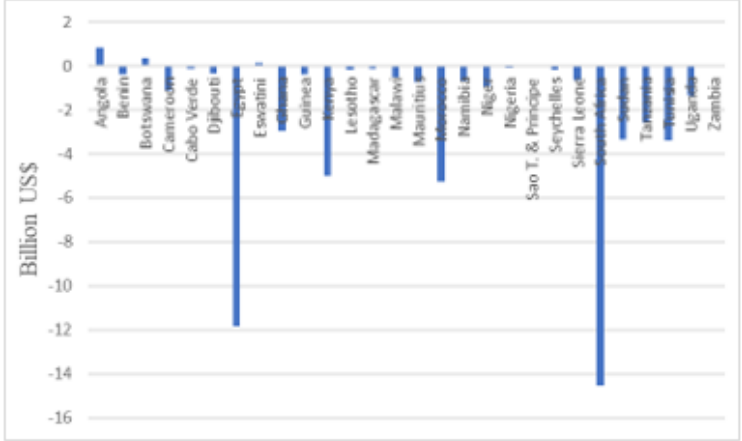

Figure 7. Development of the balances of financial accounts of the sample of African countries

Source: World Bank, World Development Indicators Data Base.

It can be said that the African continent is showing very poor performance regarding the institutional quality indicators where just a few African countries managed to achieve very modest records in a limited number of the six institutional quality indicators. Figure 8 shows that just five African countries, in the sample, managed to achieve very modest records, ranging from 0 to 1 point, in more than three institutional indicators through the period 2002-2010, namely Botswana, Caba Verde, Mauritius, Namibia, and South Africa. On the other side, fifteen African countries in the sample recorded negative points in the six institutional indicators during the same period, namely Angola, Djibouti, Cameroon, Egypt, Eswatini, Guinea, Kenya, Madagascar, Morocco, Niger, Nigeria, Sierra Leone, Sudan, Tanzania, and Uganda. The remaining countries in the sample recorded positive points in one or two indicators, at most, of the six institutional indicators.

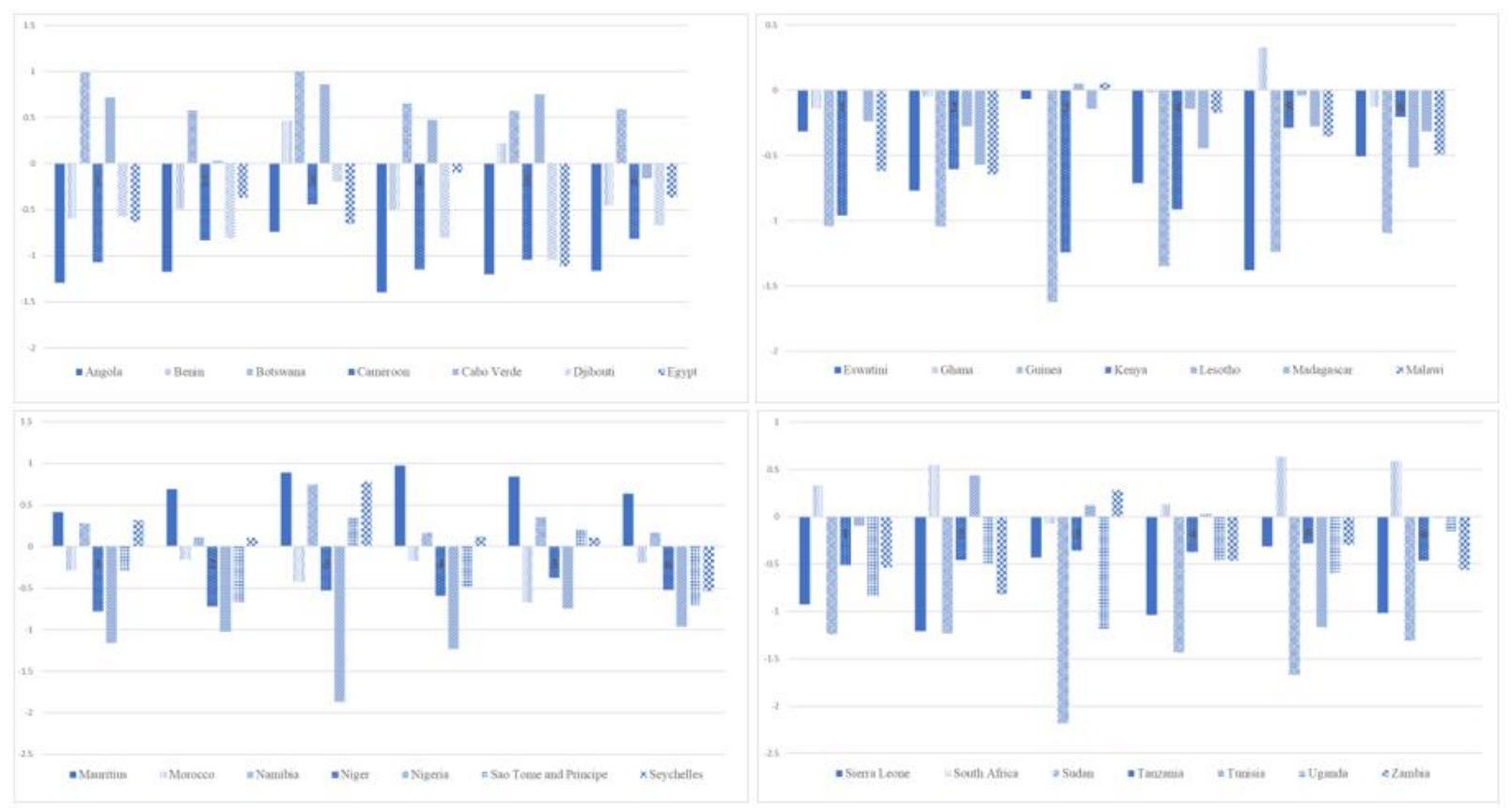

Figure 8. Development of institutional quality indicators of the sample of African countries (2002-2010)

Source: World Bank, Worldwide Governance Indicators database.

Through the period 2011-2019, Botswana, Cabo Verde, Mauritius, Namibia, and South Africa, managed to maintain their modest records in the positive area, while the records of the countries in the negative area became much worse, where some indicators reached or almost were close to -2 points as depicted in Figure 9. 


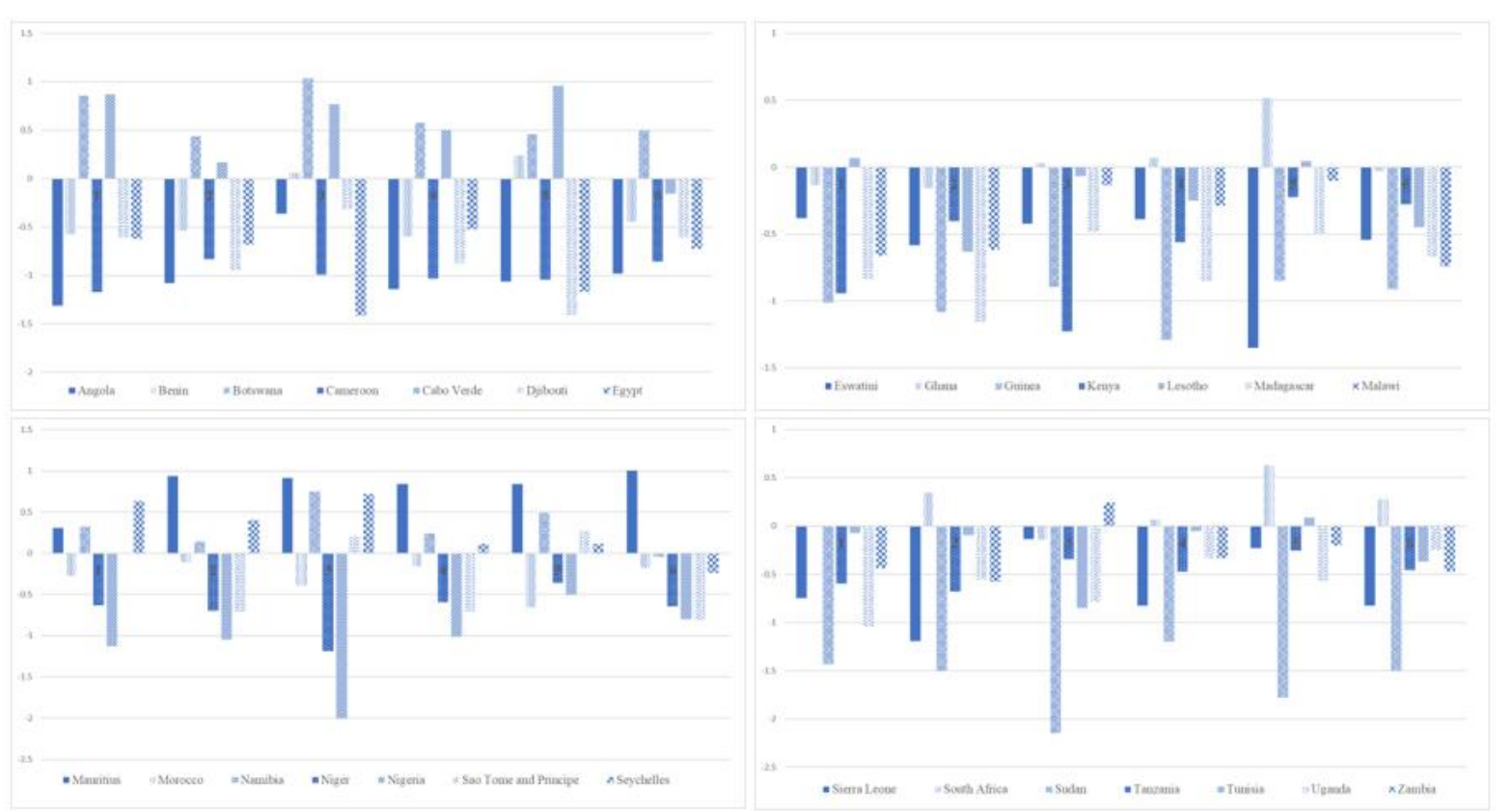

Figure 9. Development of institutional quality indicators of the sample of African countries (2011-2019)

Source: World Bank, Worldwide Governance Indicators database.

\section{Econometric Analysis and Empirical Findings}

This section examines the effect of the institutional indicators on international trade and financial transactions in the reference and African countries through applying the panel autoregressive distributed lag (ARDL) model, Akaike info criterion (AIC).

\subsection{Specifying the Model}

The generalized autoregressive distributed lag (ARDL) model has been built based on the following function:

$$
y_{n t}=f\left(y_{n, t-k}, x_{1 n t}, x_{1 n, t-v}, x_{2 n t}, x_{2 n, t-v}, x_{3 n t}, x_{3 n, t-v}, x_{4 n t}, x_{4 n, t-v}, x_{5 n t}, x_{5 n, t-v}, x_{6 n t}, x_{6 n, t-v}\right)
$$

Where $y$ is the dependent variable and it represents the balances of current and financial accounts of the countries balance of payments, $k$ represents the lags of the dependent variables, $v$ represents the lags of the independent variables or the regressors, $x_{1}$ represents control of corruption, $x_{2}$ represents government effectiveness, $x_{3}$ represents political stability and absence of violence, $x_{4}$ represents rule of law, $x_{5}$ represents voice and accountability, and $x_{6}$ represents regulatory quality.

The generalized model is represented as follows:

$$
y_{n t}=\sum_{k=1}^{K} \Theta_{n} y_{n, t-k}+\sum_{v=0}^{V} \beta_{n, t-v} x_{n, t-v}+\varphi_{n}+\varepsilon_{n t}
$$

Where $\Theta$ represents the coefficients of the lagged dependent variables, $\beta$ represents the coefficients of the independent variables, $\varphi$ represents the unit-specific fixed effect, and $\varepsilon$ represents the error term.

The error correction model or the re-parameterized ARDL model is represented as follows:

$$
\Delta y_{n t}=\theta_{n} \underbrace{y_{n, t-1}-\psi_{n} x_{n t}}_{\text {Error Correction Term }})+\sum_{k=1}^{K-1} \xi_{n t} \Delta y_{n, t-k}+\sum_{v=0}^{V-1} \beta_{n t}^{\prime} \Delta x_{n, t-v}+\varphi_{n}-\varepsilon_{n t}
$$

Where $\theta$ is the coefficient of the error correction term and it indicates the speed of correcting the short-term deviations, $\psi$ represents the long-run relationships vector, $\xi$ and $\beta^{\prime}$ are the short-term dynamic coefficients.

\subsection{Stationarity Test}

The stationarity of the model variables has been examined through the unit root test, Levin, Lin \& Chu t method. The test revealed that all the model variables are stationary, whether at level or the first difference, see appendix (A). 


\subsection{The Empirical Findings Regarding the Reference Countries}

The coefficients of the error correction terms are negative and statistically significant at a $1 \%$ significance level indicating the occurrence of convergence from short-term to long-term. In other words, a causal long-run relationship is running from the regressors to the dependent variables. Accordingly, it can be said that institutional quality indicators have long-run effects on the balances of current and financial accounts of the reference countries, see appendices (B-1) and (B-2).

\subsubsection{Institutional Quality Indicators and Current Accounts' Balances}

Control of corruption, rule of law, and voice and accountability have long-run negative impacts on the current accounts' balances, and these relationships are statistically significant at a $1 \%$ significance level with coefficients of $-46.5,-62.6$, and -33 , respectively. Political stability and absence of violence has a long-run positive effect on the current accounts' balances and this relationship is statistically significant at a $1 \%$ significance level with a coefficient of 43.5. The institutional indicators have no significant effect on the current accounts in the short-run where none of the regressors is statistically significant, see appendix (B-1).

\subsubsection{Institutional Quality Indicators and Financial Accounts' Balances}

Control of corruption, political stability and absence of violence, and voice and accountability have negative impacts on the financial accounts' balances, and these relationships are statistically significant at a $1 \%$ significance level with coefficients of -97.6, -27.1, and -24.1, respectively. Moreover, government effectiveness negatively affects the balances of financial accounts with a coefficient of -52.4 and at a significance level of $5 \%$. Rule of law and regulatory quality have positive effects on the financial accounts' balances, and the two relationships are statistically significant at a $1 \%$ significance level with coefficients of 152.8 and 101.4, respectively. What is worth noting is that in the short-run, the rule of law indicator has had a negative impact on the financial accounts' balances; however, this relationship turned into a positive relation, in the long run, see appendix (B-2).

\subsection{The Empirical Findings Regarding the Sample of African Countries}

The statistical outcomes support the validity of long-run causality running from the institutional quality indicators to the current and financial accounts of the sample of African countries, see appendices (C-1) and (C2).

\subsubsection{Institutional Quality Indicators and Current Accounts’ Balances}

Control of corruption, rule of law, voice and accountability, and regulatory quality have long-run negative impacts on the current accounts' balances, and these relationships are statistically significant at a $1 \%$ significance level with coefficients of $-0.47,-0.95,-0.48$, and -1.35 , respectively. Government effectiveness has a long-run positive effect on the current accounts' balances and this relationship is statistically significant at a $5 \%$ significance level with a coefficient of 0.7. Control of corruption and regulatory quality indicators have had positive impacts on the balances of the current accounts in the short run; however, the signs of the two relationships turned negative in the long run, see appendix (C-1).

\subsubsection{Institutional Quality Indicators and Financial Accounts' Balances}

Political stability and absence of violence, voice and accountability, and regulatory quality have positive impacts on the financial accounts' balances, and these relationships are statistically significant at a $1 \%$ significance level with coefficients of $1,0.8$, and 0.85 , respectively. Government effectiveness has a long run negative effect on the financial accounts' balances, and this relationship is statistically significant at a $1 \%$ significance level with a coefficient of -0.28 . Despite control of corruption has had a statistically short-run positive impact on the balances of the financial accounts at a $5 \%$ significance level with a coefficient of 4 ; however, this relationship became statistically insignificant in the long run, see appendix (C-2).

\section{Concluding Remarks and Recommendations}

The empirical findings of the study illustrate that, in general, the negative impact of the improvement in the institutional quality indicators on international trade and financial transactions is greater than its positive effect. Accordingly, it can be said that the advanced performance in international trade and finance achieved by the reference countries of the study could not be attributed to the quality of their institutional frameworks but rather to other factors. Political stability has a powerful long-run positive effect on the current accounts' balances of the reference countries and the financial accounts' balances of the African countries sample. Despite the rule of law plays a significant role in supporting international financial transactions in the reference countries in the long run; however, it has no significant role in supporting international trade and finance in the African countries 
whether in the short or long run. Control of corruption has positive effects on both the current and financial accounts' balances just in the short-run. Regulatory quality positively affects the financial accounts of the reference and African countries in the long run; however, its support disappears for the current accounts of both reference and African countries. On the contrary, its impact on current accounts becomes negative for African countries in the long term.

The empirical findings illustrate that the institutional indicators that support the current accounts, in the long run, are not the same that support the financial accounts. This finding supports the validity of the second hypothesis of the study. In addition, it seems that the effect of institutional indicators on international transactions is related to the level of economic development, where the effect of institutional indicators on countries with relatively low levels of economic development is more powerful than their effects on countries with advanced levels of development. Thus, the low quality of the institutional framework is considered an important impediment to the development of international transactions in African countries. This finding supports the validity of the first hypothesis of the study.

Table 1 summarizes the empirical findings of the study for the two sample countries, the reference and the African countries, in both the long- and short-run.

Table 1. Summary of the empirical findings of the study

\begin{tabular}{|c|c|c|c|c|c|c|c|c|}
\hline \multirow{4}{*}{ Institutional Indicators } & \multicolumn{4}{|c|}{ Reference Countries } & \multicolumn{4}{|c|}{ African Countries } \\
\hline & \multicolumn{8}{|c|}{ Current Accounts } \\
\hline & \multicolumn{2}{|c|}{ Short-Run } & \multicolumn{2}{|c|}{ Long-Run } & \multicolumn{2}{|c|}{ Short-Run } & \multicolumn{2}{|c|}{ Long-Run } \\
\hline & Coefficient & Sig. Level & Coefficient & Sig. Level & Coefficient & Sig. Level & Coefficient & Sig. Level \\
\hline Control of Corruption & - & - & -46.5 & $1 \%$ & 3.2 & $5 \%$ & -0.47 & $1 \%$ \\
\hline Government Effectiveness & - & - & -21.2 & $10 \%$ & - & - & 0.7 & $5 \%$ \\
\hline Political stability and absence of violence & - & - & 43.6 & $1 \%$ & - & - & - & - \\
\hline Rule of Law & - & - & -62.6 & $1 \%$ & - & - & -0.95 & $1 \%$ \\
\hline Voice and Accountability & - & - & -33 & $1 \%$ & - & - & -0.48 & $1 \%$ \\
\hline \multirow[t]{2}{*}{ Regulatory Quality } & - & - & - & - & 2.8 & $10 \%$ & -1.35 & $1 \%$ \\
\hline & \multicolumn{8}{|c|}{ Financial Accounts } \\
\hline \multirow[t]{2}{*}{ Institutional Indicators } & \multicolumn{2}{|c|}{ Short-Run } & \multicolumn{2}{|c|}{ Long-Run } & \multicolumn{2}{|c|}{ Short-Run } & \multicolumn{2}{|c|}{ Long-Run } \\
\hline & Coefficient & Sig. Level & Coefficient & Sig. Level & Coefficient & Sig. Level & Coefficient & Sig. Level \\
\hline Control of Corruption & - & - & -97.6 & $1 \%$ & 4 & $5 \%$ & - & - \\
\hline Government Effectiveness & - & - & -52.4 & $5 \%$ & - & - & -2.8 & $1 \%$ \\
\hline Political stability and absence of violence & - & - & -27.1 & $1 \%$ & - & - & 1 & $1 \%$ \\
\hline Rule of Law & -112.1 & $5 \%$ & 152.8 & $1 \%$ & - & - & - & - \\
\hline Voice and Accountability & - & - & -24.1 & $1 \%$ & - & - & 0.8 & $1 \%$ \\
\hline Regulatory Quality & - & - & 101.4 & $1 \%$ & 2.1 & $10 \%$ & 0.85 & $1 \%$ \\
\hline
\end{tabular}

In the context of the previous findings, African countries have to develop the status of four main institutional aspects, namely government effectiveness, political stability and absence of violence, voice and accountability, and regulatory quality, to reach advanced positions in international economics. In addition, further studies are needed to determine the turning point of the positive effect of institutional quality on international transactions and determine the complementary measures that maintain the progress of both the institutional indicators and the current and financial accounts of the balance of payments of the reference countries.

\section{References}

African Union. (2001). The New Partnership for Africa's Development. A program of the African Union. Retrieved from https://www.un.org/en/africa/osaa/pdf/nepad/nepad.pdf

Alam, R., Kitenge, E., \& Bedane, B. (2017). Government Effectiveness and Economic Growth. Economics Bulletin, 37, 222-227.

Ali, I., \& Zhuang, J. (2007). Inclusive Growth toward a Prosperous Asia: Policy Implications. ERD Working Paper Series No. 97, Economics and Research Department, Asian Development Bank, Manila. Retrieved from http://hdl.handle.net/11540/1858

Butkus, M., \& Seputiene, J. (2018). Growth Effect of Public Debt: The Role of Government Effectiveness and Trade Balance. Economies, 6, 62. https://doi.org/10.3390/economies6040062 
Duho, K. C., Amankwa, M., \& Musah-Surugu, J. I. (2020). Determinants and convergence of government effectiveness in Africa and Asia. Public Administration and Policy, 23(2), 199-215. Emerald Publishing Limited. https://doi.org/10.1108/PAP-12-2019-0039

Emara, N., \& Chiu, I. (2016). The Impact of Governance Environment on Economic Growth: The Case of Middle Eastern and North African Countries. Topics in Middle Eastern and African Economies, 18(1). Retrieved from http://www.luc.edu/orgs/meea/

Fayissa, B., \& Nsiah, B. C. (2013). The Impact of Governance on Economic Growth in Africa. The Journal of Developing Areas, 47, 108 - 91. https://doi.org/10.1353/jda.2013.0009

Hall, R., \& Jones, C. I. (1998). Why Do Some Countries Produce So Much More Output Per Worker than Others? The Quarterly Journal of Economics, 114(1), 83-116. https://doi.org/10.1162/003355399555954

Han, X., Khan, H., \& Johnson, T. (2014). Do Governance Indicators Explain Development Performance? A Cross-Country Analysis. Political Economy - Development: Political Institutions eJournal. https://doi.org/10.2139/ssrn.2558894

Hayat, A., Hayat, A., \& Hayata, A. (2019). Foreign Direct Investments, Institutional Framework and Economic Growth. IES Working Paper, No. 09/2017, Charles University in Prague, Institute of Economic Studies (IES), Prague. https://doi.org/10.1080/09638199.2018.1564064

Joffe, M. (2017). Evidence and the micro-foundations of economic growth. Economics and Business Review, 3(17), 52-79. https://doi.org/10.18559/ebr.2017.3.4

McQuinn, K., \& Whelan, K. (2007). Conditional convergence and the dynamics of the capital-output ratio. Journal of Economic Growth, 12, 159-184. DOI: https://doi.org/10.1007/s10887-007-9013-3

Montes, G., Bastos, J. C., \& Oliveira, A. J. (2019). Fiscal transparency, government effectiveness and government spending efficiency: Some international evidence based on panel data approach. Economic Modelling, 79, 211-225. https://doi.org/10.1016/j.econmod.2018.10.013

Nikzadian, A., Agheli, L., Arani, A. A., \& Sadeghi, H. (2019). The Effects of Resource Rent, Human Capital and Government Effectiveness on Government Health Expenditure in Organization of the Petroleum Exporting Countries. International Journal of Energy Economics and Policy, 9, 381-389. https://doi.org/10.32479/ijeep.7575

North, D., \& Thomas, R. P. (1973). The Rise of the Western World: A New Economic History. Cambridge: Cambridge University Press. https://doi.org/10.1111/aehr.152br15

Osabuohien, S. E. (2011). Analysis of International Trade Performance in Selected Sub-Saharan African Countries: Impact of Institutional Framework (Published doctoral dissertation). Covenant University, Ota, Nigeria.

Radulović, M. (2020). The impact of institutional quality on economic growth: A comparative analysis of the EU and non-EU countries of Southeast Europe. Ekonomski Anali, 65, 163-181. https://doi.org/10.2298/EKA2025163R

Sabir, S., Rafique, A., \& Abbas, K. (2019). Institutions and FDI: evidence from developed and developing countries. Financial Innovation, 5, 1-20. https://doi.org/10.1186/s40854-019-0123-7

Samarasinghe, T. (2018). Impact of Governance on Economic Growth. MPRA Paper No. 89834. Retrieved from https://mpra.ub.uni-muenchen.de/id/eprint/89834

Şaşmaz, M. Ü., \& Sağdiç, E. N. (2020). The Effect of Government Effectiveness and Rule of Law on Economic Growth: The Case of European Union Transition Economies. Işsletme Fakültesi Dergisi, 21(1), 203-217. https://doi.org/10.24889/ifede.729490

Shah, A., \& Huther, J. (1999). Applying a Simple Measure of Good Governance to the Debate on Fiscal Decentralization. Policy Research Working Paper. Washington, DC: The World Bank. https://doi.org/10.1596/1813-9450-1894

Solow, R. (1956). A Contribution to the Theory of Economic Growth. Quarterly Journal of Economics, 70, 6594. https://doi.org/10.2307/1884513

Tharnpanich, N., \& Mccombie, J. (2013). Balance-of-payments constrained growth, structural change, and the Thai economy. Journal of Post Keynesian Economics, 35, 569 - 598. https://doi.org/10.2753/PKE01603477350404 


\section{Appendix}

\section{Appendix A. Unit Root Test (Stationarity Test)}

\begin{tabular}{|c|c|c|c|}
\hline \multicolumn{4}{|c|}{ Reference Countries Group } \\
\hline \multirow{2}{*}{ Variable } & \multirow{2}{*}{ Stationarity Status } & \multicolumn{2}{|c|}{ Levin, Lin \& Chu t } \\
\hline & & Statistic & Probability \\
\hline \multirow{2}{*}{ Current Account Balance (Y1) } & Level & -3.23735 & 0.0006 \\
\hline & First Level & -8.41851 & 0 \\
\hline \multirow{2}{*}{ Financial Account Balance (Y2) } & Level & -2.78834 & 0.0026 \\
\hline & First Level & -9.1383 & 0 \\
\hline \multirow{2}{*}{ Control of Corruption (X1) } & Level & -1.1173 & 0.1319 \\
\hline & First Level & -3.06735 & 0.0011 \\
\hline \multirow{2}{*}{ Government Effectiveness (X2) } & Level & -2.51868 & 0.0059 \\
\hline & First Level & -3.36158 & 0.0004 \\
\hline \multirow{2}{*}{ Political Stability No Violence (X3) } & Level & -1.36681 & 0.0858 \\
\hline & First Level & -5.80014 & 0 \\
\hline \multirow{2}{*}{ Rule of Law (X4) } & Level & -1.38127 & 0.0836 \\
\hline & First Level & -5.09336 & 0 \\
\hline \multirow{2}{*}{ Voice and Accountability (X5) } & Level & -4.43588 & 0 \\
\hline & First Level & -12.4371 & 0 \\
\hline \multirow{2}{*}{ Regulatory Quality (X6) } & Level & -0.06919 & 0.4724 \\
\hline & First Level & -3.79316 & 0.0001 \\
\hline \multicolumn{4}{|c|}{ African Countries Group } \\
\hline \multirow{2}{*}{ Variable } & \multirow{2}{*}{ Stationarity Status } & \multicolumn{2}{|c|}{ Levin, Lin \& Chu t* } \\
\hline & & Statistic & Probability \\
\hline \multirow{2}{*}{ Current Account Balance (Y1) } & Level & -3.51976 & 0.0002 \\
\hline & First Level & -12.7339 & 0 \\
\hline \multirow{2}{*}{ Financial Account Balance (Y2) } & Level & -3.57790 & 0.0002 \\
\hline & First Level & -10.7233 & 0 \\
\hline \multirow{2}{*}{ Control of Corruption (X1) } & Level & -0.08930 & 0.4644 \\
\hline & First Level & -7.11266 & 0 \\
\hline \multirow{2}{*}{ Government Effectiveness (X2) } & Level & -3.77632 & 0.0001 \\
\hline & First Level & -12.3516 & 0 \\
\hline \multirow{2}{*}{ Political Stability No Violence (X3) } & Level & -3.85349 & 0.0001 \\
\hline & First Level & -6.77040 & 0 \\
\hline \multirow{2}{*}{ Rule of Law (X4) } & Level & -2.50548 & 0.0061 \\
\hline & First Level & -8.59616 & 0 \\
\hline \multirow{2}{*}{ Voice and Accountability (X5) } & Level & -2.40871 & 0.0080 \\
\hline & First Level & -5.74163 & 0 \\
\hline \multirow{2}{*}{ Regulatory Quality (X6) } & Level & -1.31316 & 0.0946 \\
\hline & First Level & -8.37802 & 0 \\
\hline
\end{tabular}

\section{Appendix B-1. The Effect of Institutional Indicators on the Current Accounts of the Reference Countries}

Dependent Variable: D(Y1)

Method: ARDL

Sample: 2003-2019

Included observations: 255

Maximum dependent lags: Automatic selection

Model selection method: Akaike info criterion (AIC)

Dynamic regressors (1 lag, automatic): X1 X2 X3 X4 X5 X6

Fixed regressors: $\mathrm{C}$

Number of models evaluated: 3

Selected Model: ARDL $(1,1,1,1,1,1,1)$

\begin{tabular}{ccccc}
\hline Variable & Coefficient & Std. Error & t-Statistic & Prob. $^{*}$ \\
\hline X1 & Long Run Equation & & 0.0060 \\
X2 & -46.54755 & 16.67952 & -2.790700 & 0.0869 \\
X3 & -21.17032 & 12.28312 & -1.723529 & 0.0000 \\
X4 & 43.57092 & 8.943210 & 4.871956 & 0.0026 \\
X5 & -62.63488 & 20.41328 & -3.068340 & 0.0006 \\
X6 & -33.04429 & 9.389226 & -3.519384 & 0.1786 \\
\hline
\end{tabular}




\begin{tabular}{|c|c|c|c|c|}
\hline \multicolumn{5}{|c|}{ Short Run Equation } \\
\hline COINTEQ01 & -0.354159 & 0.054343 & -6.517131 & 0.0000 \\
\hline $\mathrm{D}(\mathrm{X} 1)$ & 16.25766 & 19.86451 & 0.818428 & 0.4145 \\
\hline $\mathrm{D}(\mathrm{X} 2)$ & 0.584009 & 14.09993 & 0.041419 & 0.9670 \\
\hline $\mathrm{D}(\mathrm{X} 3)$ & -0.078675 & 7.764799 & -0.010132 & 0.9919 \\
\hline $\mathrm{D}(\mathrm{X} 4)$ & -25.63223 & 21.12391 & -1.213422 & 0.2270 \\
\hline $\mathrm{D}(\mathrm{X} 5)$ & 29.47193 & 29.54696 & 0.997461 & 0.3202 \\
\hline $\mathrm{D}(\mathrm{X} 6)$ & -26.98613 & 25.62265 & -1.053214 & 0.2940 \\
\hline $\mathrm{C}$ & 65.51853 & 16.50335 & 3.970014 & 0.0001 \\
\hline Mean dependent var & 3.215594 & \multicolumn{2}{|c|}{ S.D. dependent var } & 26.94448 \\
\hline S.E. of regression & 26.15001 & \multicolumn{2}{|c|}{ Akaike info criterion } & 8.191784 \\
\hline Sum squared resid & 98470.50 & \multicolumn{2}{|c|}{ Schwarz criterion } & 9.871047 \\
\hline Log likelihood & -979.8908 & \multicolumn{2}{|c|}{ Hannan-Quinn criter. } & 8.866103 \\
\hline
\end{tabular}

Appendix B-2. The Effect of Institutional Indicators on the Financial Accounts of the Reference Countries

Dependent Variable: D(Y2)

Method: ARDL

Sample: 20032019

Included observations: 255

Maximum dependent lags: Automatic selection

Model selection method: Akaike info criterion (AIC)

Dynamic regressors (1 lag, automatic): X1 X2 X3 X4 X5 X6

Fixed regressors: $\mathrm{C}$

Number of models evaluated: 3

Selected Model: ARDL $(1,1,1,1,1,1,1)$

\begin{tabular}{|c|c|c|c|c|}
\hline Variable & Coefficient & Std. Error & $\mathrm{t}$-Statistic & Prob.* \\
\hline \multicolumn{5}{|c|}{ Long Run Equation } \\
\hline $\mathrm{X} 1$ & -97.64771 & 13.35512 & -7.311632 & 0.0000 \\
\hline $\mathrm{X} 2$ & -52.44914 & 23.96966 & -2.188147 & 0.0303 \\
\hline $\mathrm{X} 3$ & -27.11251 & 9.510090 & -2.850921 & 0.0050 \\
\hline $\mathrm{X} 4$ & 152.7888 & 18.82348 & 8.116923 & 0.0000 \\
\hline $\mathrm{X} 5$ & -24.16040 & 9.310908 & -2.594849 & 0.0104 \\
\hline X6 & 101.4383 & 21.59826 & 4.696598 & 0.0000 \\
\hline \multicolumn{5}{|c|}{ Short Run Equation } \\
\hline COINTEQ01 & -0.357769 & 0.079251 & -4.514375 & 0.0000 \\
\hline $\mathrm{D}(\mathrm{X} 1)$ & 2.896242 & 45.34075 & 0.063877 & 0.9492 \\
\hline $\mathrm{D}(\mathrm{X} 2)$ & 8.584813 & 22.62560 & 0.379429 & 0.7049 \\
\hline $\mathrm{D}(\mathrm{X} 3)$ & 20.50218 & 18.65105 & 1.099250 & 0.2735 \\
\hline $\mathrm{D}(\mathrm{X} 4)$ & -112.1636 & 47.71797 & -2.350552 & 0.0201 \\
\hline $\mathrm{D}(\mathrm{X} 5)$ & 70.29850 & 50.54384 & 1.390842 & 0.1664 \\
\hline $\mathrm{D}(\mathrm{X} 6)$ & -42.16386 & 47.08943 & -0.895400 & 0.3721 \\
\hline $\mathrm{C}$ & -4.723781 & 6.897202 & -0.684884 & 0.4945 \\
\hline Mean dependent var & 3.138335 & \multicolumn{2}{|c|}{ S.D. dependent var } & 36.07859 \\
\hline S.E. of regression & 31.02918 & \multicolumn{2}{|c|}{ Akaike info criterion } & 8.756661 \\
\hline Sum squared resid & 138644.7 & \multicolumn{2}{|c|}{ Schwarz criterion } & 10.43592 \\
\hline Log likelihood & -1056.149 & \multicolumn{2}{|c|}{ Hannan-Quinn criter. } & 9.430980 \\
\hline
\end{tabular}

\section{Appendix C-1. The Effect of Institutional Indicators on the Current Accounts of the African Countries}

Dependent Variable: D(Y1)

Method: ARDL

Sample: 2003-2019

Included observations: 476

Maximum dependent lags: Automatic selection

Model selection method: Akaike info criterion (AIC)

Dynamic regressors (1 lag, automatic): X1 X2 X3 X4 X5 X6

Fixed regressors: $\mathrm{C}$

Number of models evaluated: 3

Selected Model: ARDL $(1,1,1,1,1,1,1)$ 


\begin{tabular}{|c|c|c|c|c|}
\hline Variable & Coefficient & Std. Error & t-Statistic & Prob.* \\
\hline \multicolumn{5}{|c|}{ Long Run Equation } \\
\hline $\mathrm{X} 1$ & -0.471527 & 0.174100 & -2.708370 & 0.0072 \\
\hline $\mathrm{X} 2$ & 0.704769 & 0.305577 & 2.306356 & 0.0218 \\
\hline $\mathrm{X} 3$ & 0.188649 & 0.129822 & 1.453130 & 0.1473 \\
\hline $\mathrm{X} 4$ & -0.954846 & 0.330242 & -2.891350 & 0.0041 \\
\hline $\mathrm{X} 5$ & -0.479188 & 0.180892 & -2.649025 & 0.0085 \\
\hline X6 & -1.351488 & 0.239470 & -5.643669 & 0.0000 \\
\hline \multicolumn{5}{|c|}{ Short Run Equation } \\
\hline COINTEQ01 & -0.370043 & 0.073230 & -5.053143 & 0.0000 \\
\hline $\mathrm{D}(\mathrm{X} 1)$ & 3.184914 & 1.553216 & 2.050528 & 0.0413 \\
\hline $\mathrm{D}(\mathrm{X} 2)$ & -0.808420 & 0.639257 & -1.264626 & 0.2071 \\
\hline $\mathrm{D}(\mathrm{X} 3)$ & -1.066367 & 1.339650 & -0.796004 & 0.4267 \\
\hline $\mathrm{D}(\mathrm{X} 4)$ & -2.641171 & 2.570198 & -1.027614 & 0.3050 \\
\hline $\mathrm{D}(\mathrm{X} 5)$ & -1.588481 & 1.100289 & -1.443694 & 0.1500 \\
\hline $\mathrm{D}(\mathrm{X6})$ & 2.804346 & 1.515785 & 1.850094 & 0.0654 \\
\hline $\mathrm{C}$ & -0.900876 & 0.291994 & -3.085255 & 0.0022 \\
\hline Mean dependent var & -0.139954 & \multicolumn{2}{|c|}{ S.D. dependent var } & 2.992784 \\
\hline S.E. of regression & 2.626332 & \multicolumn{2}{|c|}{ Akaike info criterion } & 1.701244 \\
\hline Sum squared resid & 1889.947 & \multicolumn{2}{|c|}{ Schwarz criterion } & 3.628213 \\
\hline Log likelihood & -198.7134 & \multicolumn{2}{|c|}{ Hannan-Quinn criter. } & 2.457126 \\
\hline
\end{tabular}

\section{Appendix C-2. The Effect of Institutional Indicators on the Financial Accounts of the African Countries}

\begin{tabular}{|c|c|c|c|c|}
\hline \multicolumn{5}{|c|}{ Dependent Variable: D(Y2) } \\
\hline \multicolumn{5}{|l|}{ Method: ARDL } \\
\hline \multicolumn{5}{|l|}{ Sample: 2003-2019 } \\
\hline \multicolumn{5}{|c|}{ Included observations: 476} \\
\hline \multicolumn{5}{|c|}{ Maximum dependent lags: Automatic selection } \\
\hline \multicolumn{5}{|c|}{ Model selection method: Akaike info criterion (AIC) } \\
\hline \multicolumn{5}{|c|}{ Dynamic regressors (1 lag, automatic): X1 X2 X3 X4 X5 X6 } \\
\hline \multicolumn{5}{|l|}{ Fixed regressors: $\mathrm{C}$} \\
\hline \multicolumn{5}{|c|}{ Number of models evaluated: 3} \\
\hline \multicolumn{5}{|c|}{ Selected Model: ARDL $(1,1,1,1,1,1,1)$} \\
\hline Variable & Coefficient & Std. Error & t-Statistic & Prob.* \\
\hline \multicolumn{5}{|c|}{ Long Run Equation } \\
\hline $\mathrm{X} 1$ & -0.183822 & 0.256803 & -0.715810 & 0.4747 \\
\hline $\mathrm{X} 2$ & -2.787263 & 0.354732 & -7.857370 & 0.0000 \\
\hline $\mathrm{X} 3$ & 1.077882 & 0.113170 & 9.524451 & 0.0000 \\
\hline $\mathrm{X} 4$ & 0.234869 & 0.292264 & 0.803617 & 0.4223 \\
\hline $\mathrm{X} 5$ & 0.794062 & 0.234301 & 3.389067 & 0.0008 \\
\hline X6 & 0.854786 & 0.252136 & 3.390174 & 0.0008 \\
\hline \multicolumn{5}{|c|}{ Short Run Equation } \\
\hline COINTEQ01 & -0.454329 & 0.060555 & -7.502740 & 0.0000 \\
\hline $\mathrm{D}(\mathrm{X} 1)$ & 3.991814 & 2.056014 & 1.941531 & 0.0532 \\
\hline $\mathrm{D}(\mathrm{X} 2)$ & 1.594119 & 2.041008 & 0.781045 & 0.4355 \\
\hline $\mathrm{D}(\mathrm{X} 3)$ & -0.120643 & 1.329064 & -0.090773 & 0.9277 \\
\hline $\mathrm{D}(\mathrm{X} 4)$ & -2.995565 & 2.423061 & -1.236273 & 0.2174 \\
\hline $\mathrm{D}(\mathrm{X} 5)$ & 0.918601 & 1.765253 & 0.520379 & 0.6032 \\
\hline $\mathrm{D}(\mathrm{X} 6)$ & 2.148276 & 1.234007 & 1.740894 & 0.0828 \\
\hline $\mathrm{C}$ & -0.742632 & 0.204214 & -3.636541 & 0.0003 \\
\hline Mean dependent var & -0.126193 & \multicolumn{2}{|c|}{ S.D. dependent var } & 3.406338 \\
\hline S.E. of regression & 2.617546 & \multicolumn{2}{|c|}{ Akaike info criterion } & 2.199798 \\
\hline Sum squared resid & 1877.324 & \multicolumn{2}{|c|}{ Schwarz criterion } & 4.126768 \\
\hline Log likelihood & -324.3492 & \multicolumn{2}{|c|}{ Hannan-Quinn criter. } & 2.955680 \\
\hline
\end{tabular}

\section{Copyrights}

Copyright for this article is retained by the author(s), with first publication rights granted to the journal.

This is an open-access article distributed under the terms and conditions of the Creative Commons Attribution license (http://creativecommons.org/licenses/by/4.0/). 